\title{
Validation Counselling: A catalyst for Learning to Make Appropriate Linguistic Choices
}

Thelma L. Borodkin

I will describe how I use validation counselling and consciousness raising in language teaching. The technique suggested here contains an affective component, addressing learners' feelings about the linguistic codes they use. Learners are also encouraged to take responsibility for their learning by making their own linguistic choices.

As language teachers, we are aware of the wide range of linguistic achievements of our students and we are curious about the causes of those differences. Anxious to have our students make significant progress, we often ask: Why do some learners succeed while others fail? What makes a good language learner?

In this paper, I will describe how validation counselling can be used as a consciousness-raising catalyst enabling students to take charge of their learning and to make appropriate linguistic choices.

\section{Background}

From the outset, one underlying aim of the research on learning about learning was to investigate learners' perspectives in an effort to make students more independent, self-directed learners. To that end Naiman, Fröhlich, Stern and Todesco (1978) set out to identify characteristics, strategies and techniques of successful language learners through observation and interview (cf. Rubin, 1975; Stern, 1975; Wesche, 1975). Their study provided researchers much-needed information on the process of language learning from the learners' perspective while simultaneously raising learners' awareness as to what they were doing to achieve their language-learning goals. They devised an instrument for interviewing language learners; their study validated this interview procedure as a research tool which provided both teacher and learner $r$ ith the learners' perspective of language learning. Both teachers and learners could then use that information to enhance the language process by clarifying misconceptions and/ 
or changing negative attitudes toward language learning or toward themselves as learners.

Wenden (1982) refined that instrument in her study of the self-directed learner. The self-directed learners make the decisions about their language learning rather than responding solely to the demands of the institution of which they are a part. This instrument helps students gain a high level of control over the language-learning process through increased awareness and evaluation of their learning strategies. The research reports, as will be cited below, that both awareness and strategy information are necessary for successful language learning.

Equally interested in the variation in students' rate and level of achievement in a new language, Rubin (1975) describes the characteristics of good language learners, and, in her book written with Thompson in 1982, suggests to language learners how they can become better, more efficient learners. This book can be used by teachers in their work with language learners as they discuss alternative learning strategies.

Horwitz (1981) describes her Beliefs About Language Learning Inventory or BALLI. The BALLI reflects her view that learners' beliefs about language learning infuence their approach to language learning and possibly their progress. This inventory contains a number of statements to which respondents are asked to indicate the degree of their agreement or disagreement. Information from the use of the inventory is then used for discussions with learners and/or for teachers' evaluation of teaching methods. Horwitz claims that the use of the BALLI has been very helpful in her work with groups of anxious language learners, many of whom erroneously believed that they were supposed to understand every word in their foreign language class. Being told that there is no such expectation and that none of the other students understood every word helped the students to relax and discuss alternate ways to listen to a foreign language to improve their learning. Horwitz also reports that other teachers, who have used the BALLI in the intensive English Program at the University of Texas, laud its effectiveness as a discussion stimulus at the onset of ESL classes to help students develop more effective learning strategies. Users of the BALLI indicate that discussions initiated by its use are informative to both teachers and students. For example, such discussions enable students to examine their beliefs about how long it takes to learn a new language at the college level. If they underestimate the difficulty of the task, as many students tend to do, frustration and anger inevitably follow. Moreover, Horwitz reports that many students strongly believe that learning vocabulary lists and grammar rules is the best way to learn a language. They were surprised to find that other strategies could be added to those they use to make their language learning more productive. Finally, Hor- 
witz indicates that other studies on the BALLI are underway and she suggests areas for future research (1987:125).

\section{Validation Counselling}

Validation counselling is loosely based on the work of Rogers (1951). In his book, Client-Centered Therapy, he discusses the adaptation of this kind of counselling to educational institutions. Those principles which I have adapted to the ESL classroom are best expressed by Cantor (1946):

- The teacher will be concerned primarily with understanding and not judging the individual.

- The teacher will keep at the center of the teaching process the importance of the student's problems and feelings, not his/her own.

- Most important of all, the teacher will realize that constructive effort must come from the positive or active forces within the students. (pp. 83-84)

Validation counselling consists of three steps. The first is validation. At this stage, the important goal is to legitimize whatever it is that the client is feeling or doing. The critical aspect is non-judgmental acceptance of the client.

The second step is the consideration of options. At this point, facilitator and client discuss alternative patterns of behaviour or choices. The client is encouraged to consider his/her options through a process of consideration of alternatives. For example, these might include thinking about career choices: considering the preparation involved in each choice; the demands on one's time in the career itself; the client's personality and suitability to the demands of the position; and the financial and perhaps emotional rewards offered by each career. This thinking-out-loud process has been successfully used in counselling to enable clients to gain a clearer perspective on their choices (cf. Bruffee, 1984).

The third step is evaluation, in which the client, clearly understanding the available options, is in a position to evaluate the choices and select those which are appropriate to his/her situation. It is through this process that people gain control over their lives, for they are the ones to decide on beneficial courses of action.

\section{Validation Counselling in the ESL Classroom}

In this section I will describe my application of validation counselling to the ESL students at Lehman College.

The ESL population at Lehman College is made up of newcomers to the United States, as well as those who have been here for many years. Many have come to the United States without having completed high 
school in their own country. They also have limited time and resources for furthering their education. These students range in age from 18-35; many manifest poor academic histories and are often heads of families. Their roles as parents and breadwinners are demanding and repeatedly intrude on the language-learning process whose main focus is the writing of a college-level essay in an appropriate academic style. They tend to hold certain preconceived notions which I have found are detrimental to successful language learning.

Many ESL students believe that if they had learned English as children it would have been much easier for them. After all, they argue, everybody knows that children learn language much more easily than adults do. In addition, many ESL students tend to equate, not necessarily consciously, the many errors on their papers with their value as people, e.g. "There must be something wrong with me. I can't write an error-free paper." Moreover, they feel that grammatical correctness is the sole criterion for good language. They have little appreciation for the fact that their native language is a legitimate register in their linguistic repertoire. Unfortunately, some students even view their native language as "bad" or "undesirable," reflecting the view of many native speakers toward non-native speaker immigrants.

Finally, there is much guilt about which language they should be using. On the one hand, speaking their native language is natural, comfortable and easy, yet there is that nagging feeling that they should be using English more. Accompanying this latter feeling is the belief among some students that frequent use of English is somehow disloyal to their heritage.

\section{Technique: Validation Counselling and Linguistics}

The problem for me then became how to use validation counselling in the ESL classroom in an effort to help students become informed language learners who could work with me toward a mutually-accepted goal.

Throughout the semester, I seize every opportunity for informal minidiscussions about sociolinguistic issues related to dialect variation, standard language and speech registers. Through a variety of activities, I show students that they do in fact know much about English, in spite of the many anguish-evoking red marks on their papers.

For example, students can determine the subject and the verb from sentences like the following:

The wham is whamming on the wham.

They can choose which is more or less formal: Good evening, ladies and gentlemen, or $\mathrm{Hi}$, everybody.

They can make sense of a group of words:

young boys are red-haired three the 
They can distinguish between sentences and fragments in their exercises.

We discuss under what conditions it is appropriate to say $\mathrm{Hi}$, everybody as opposed to Good evening, ladies and gentlemen.

Students are encouraged to talk about what they know of linguistic registers and show that they do know a great deal. For example, Rosenthal (1977) reports that even very young children discriminated against their playmates on linguistic bases. In my class, what learners don't know then becomes the subject for further instruction.

Secondly, we talk about options. What are the choices available to them? Everybody knows at least one person who came to this country and never learned English. On the other hand, there are those who have come and learned English well. We talk about our future, our careers, our hopes for the kind of lifestyle we want and then the question arises: Where does English fit into the picture? We do have choices. We can choose to learn English or we can choose not to learn English. Can we learn English in addition to our native language? Is there room for both? How much English should we learn? What kind of English should we learn? Why? What are the consequences of learning or not learning English? What are the shortterm effects of this choice? What are the long-term effects? The important feature of this step is that students realize that they do have a choice.

In the third step, the evaluation of the choices, students consciously think about their choices, the consequences of their choices and actively and purposefully determine which one is appropriate to their present and future needs, which may, in fact, be in conflict. This student-centred mode of instruction places the responsibility for decision-making on the learners themselves. This allows the learners to take an active role in and responsibility for their learning.

As part of this ongoing process of validation counselling, we have informal discussions on metalinguistic issues. Students are encouraged to draw on their own experiences to report on what they know about language. For example, we invariably hear the belief that the city dialect in whatever language is superior to the country dialect. We discuss this fact and relate it to their being speakers of a variety of languages and dialects. With students talking freely, we discuss what standard language means, where it comes from and why, if it is needed, and what good language is.

We go over the three factors which determine good language-subject, context, audience-and together we discover the advantages of being bilingual, of being able to communicate with more than one group of people, of having access to another culture and tradition. Most important, I stress the notion that in learning English they are adding to their linguistic capabilities not substituting one for the other.

In addition, we talk about "noise" (Shannon and Weaver, 1964) which 
causes interference in a communication channel similar to the noise on a bad telephone connection. What that noise is and how it manifests itself in speech and writing become subjects for discussion. Using the term "noise" to refer to interference on their papers, I point out how incorrect spellings or incorrect grammatical structures distract the reader and cause the reader's attention to focus on the form rather than on the meaning that they, the writers, intend to convey. Similarly, using inappropriate registers such as the language they use with friends, in academic essays, interferes with the reader's comprehension of their writing. On their papers I can then write, "Your ideas and organization are fine. We need to work on the noise."

This inductive technique of consciousness raising helps students to relate what I am saying to their own language, as they become more sensitive to, or aware of, linguistic phenomena.

Finally, we read in order to stimulate discussion. In pieces like those written by Fromkin and Rodman, we find out how dialects are not only linguistically, but politically determined, as well. We read about language learning strategies in O'Maggio (1978) in Rubin and Thompson's book, and we discuss the BALLI; in Postman's article "The Demeaning of Meaning," (1974) we learn about language pollution and then discuss the importance of clarity and specificity in our writing; we read from Kazin's "A Walker in the City" (1975) and discuss his being the first English speaker in his family.

\section{The Student/Guest Speakers}

The advantages of peer tutoring and peer instruction are well documented. Thus, although I can give students much information that they seem to need, the introduction of a peer, guest speaker, offsets the imbalance of "teacher" and all the accompanying connotations.

Each semester I invite one of my now successful former students, who had had a difficult time with English, to come to speak to my current class. I simply ask the speaker to relate his/her language-learning experiences. In the course of the presentation, I behave as a regular participant in the discussion. In that role I am able to raise metalinguistic issues via validation counselling.

Within this discussion format, I am also able to introduce new facts. For example, I dispel the myth of the ease of child second language acquisition vs. adult second language acquisition. I get this information from students inductively. I ask questions such as: What does a child's language look like? Does a child need to know what you need to know about English? How do people react when a child mispronounces a word? Do they react the same way when your pronunciation is not clear? 
On two noteworthy occasions former students came and discussed their language-learning experiences.

Ana's report was remarkable in that she could articulate the approach that she found to be appropriate to her language-learning needs. This level of awareness of her language-learning process enabled her to plan the appropriate learning strategies to be used to enhance her language learning. Without knowing the words, Ana was using metacognitive strategies. She had knowledge about her language-learning process which then enabled her to plan what she needed to do, i.e. regulatory skills.

For example, she explained that she had kept all the English papers she had written since she first entered Lehman College. She explained how she reviewed her earlier writing to examine structure and vocabulary and to compare that early writing with what she does now. She told the class that when she gets depressed, she always goes back to that earlier work to get concrete evidence of her progress in English. She described what she is doing now in preparation for the passing of the College Writing Examination, a requirement for graduation, which Ana has, so far, not successfully passed. After Ana left the class, students were asked to write their reaction to what they had heard. For homework, they were asked to write an essay on three things they should do to learn English. Every student handed in an essay at the next class meeting, which is an unusual occurrence among these students.

Sharon, another former student, came to talk to the class in the fall of 1987. Her background was different from Ana's in that she had been exposed to English early in her life. Her father was American and her mother Puerto Rican, so although she had heard some English in her life (her parents divorced when she was very young), her written English was problematic. Sharon explained her difficulty in realizing that, although she knew some English, it was not the variety she needed for her college work. Some of the students in the class understood what she meant, for they had not had the opportunity to go to school when they first came and had picked up the kind of English they heard in their neighbourhood, a variety which was totally inappropriate for most of their college purposes.

Throughout her talk, Sharon included information about the various strategies she had used. She told the students that she was not afraid to risk being wrong. She explained how she continuously rewrote her essays and asked questions about why something was wrong. She tried to impress on her listeners the importance of asking questions immediately rather than postponing the asking to preclude additional confusion. She also told the class how she experimented with different structures and tried out new words to see whether she really knew how to use them. Moreover, she explained the importance of guessing meanings from context and practically gave them her own lesson on how to write an introduction to an 
essay. Finally, she pointed out that she felt good because she was continuously learning; I pointed out to the class the fact that Sharon never lost her courage, nor did she complain about the amount of work that she had to do.

The characteristics that distinguish these guest speakers are their awareness of the language-learning process, their purposeful choice of techniques, and their constant evaluation or monitoring of their progress. This phenomenon, as reported in the literature on learning about learning, is found in those learners who have mastered metacognition and who not only use a variety of cognitive learning strategies, but do the monitoring as well. In addition, these students seem to be aware of their feelings and have invented successful coping mechanisms for dealing with that aspect of language learning.

This level of awareness of the language-learning process is largely unavailable to many ESL students. For example, when asked what they should do to improve their writing, students often respond that they should write more essays. Such students lack an awareness of their need to evaluate their progress in general and, more specifically, to focus on particular problems in their work. They don't realize the value of examining their previous work as one means of deciding on more productive learning strategies. They seem to believe that "doing more of the same", in and of itself, will somehow be useful.

To my knowledge, these discussions of the process of second language learning are a new experience for these ESL students who have never before thought about their language-learning process in a conscious, deliberate way. Their reports on their evaluation of the guest speakers seem to confirm this observation.

\section{Discussion}

Validation counselling is used to help learners appreciate their native language as a legitimate language which has a critical function to play in their linguistic repertoire for all the reasons that people need to communicate. Moreover, validation counselling, used with the accompanying technique of consciousness raising, helps many learners believe more strongly in themselves as language learners and their capabilities as "academics" despite the poor academic histories that many students have. Finally, validation counselling gives the control of their learning to the learners themselves who need to take responsibility for their actions as they do in other areas of their lives.

The ongoing process of consciousness raising about linguistic issues helps students gain both the awareness of the process of second language acquisition and knowledge of successful learning strategies. Wenden 
(1987), Stevick (1976), and others have reported that both elements are necessary for good language learning. Many students realize that learning a new language at the college level is a lengthy process. Raising their consciousness as to their beliefs about language learning and their views of themselves as language learners through validation counselling decreases many students' level of anger, frustration, and anxiety.

The student responses are almost universally positive and appreciative of both the guest speakers' efforts and accomplishments and their willingness to share their language-learning experiences with others. Students often write how this guest speaker has inspired them to go on with the difficult task they face. Others point to their realization, often for the first time, that everybody experiences similar difficulties in the learning of a new language and that they are not the only ones with language-learning problems. These understandings help to lower their level of anxiety, while misconceptions about language learning for adults and children lead to more realistic expectations of their speech and greater appreciation of the advantages they have as adult language learners. Finally, many students begin to feel that they are in control of their learning; they are freed from their feelings of helplessness and sole reliance on the teacher as the "knower."

\section{Conclusion}

Through the process of validation counselling it seems possible to create a beneficial environment within a rather rigidly institution-imposed framework for instruction. Consciousness raising can act as a catalyst enabling many students to gain insight into language learning. One language is not a substitute for the other, but rather, each enriches and expands the users' capabilities, when used appropriately.

At the end of the course, many students have a greater understanding of the process of second language acquisition, resulting in more positive and productive attitudes leading to assuming the very active role that they must play in the process of becoming advanced users of a second language. Success, defined in terms of this paper, means students' realization that they need to take responsibility for their linguistic choices.

We have little control over the environment outside our classrooms. We do, however, have much control over what goes on inside our classrooms.

We do not want to go back a half century to renew the belief held by many new immigrants that their language was to be discarded in favor of the "pristine English" so eloquently described by Kazin in his "Walker in the City." Neither do we want a generation of Mrs. Lados. Her son, Robert Lado (1957), dedicated his book to "Mother, monolingual Spanish speaker in the United States." We do, however, want to educate students 
who take charge of their learning and know how to make appropriate linguistic choices.

\section{REFERENCES}

Borodkin, Thelma L. Ethnicity and Linguistics: New Partners in the Education of Modern Urban Populations. Working Papers in Linguistics, \#3, Newark Delaware: University of Delaware Press, 1980.

Borodkin, Thelma L. Teaching Writing through Consciousness-Raising about Language. Diss. Union Graduate School, 1977a.

Borodkin, Thelma L. Appropriate vs. Correct: Why Ain't Can't Be Alive and Well in the English Classroom. Classroom. Seattle, Washington: Rational Island Publishers, 1977b.

Bruffee, Kenneth A. Collaborative Learning and the Conversation of Mankind. College English, vol. 46, \#7, Nov. 1984, pp. 635-652.

Cantor, Neil. The Dynamics of learning. Buffalo: Foster and Stewart, 1946.

Fishman, Joshua A. Course on Bilingual Education for Teachers. Teachers College, Columbia University, 1977.

Fromkin, Victoria and Robert Rodman. An Introduction to Language. 3rd ed. New York: Holt, Rinehart and Winston, 1983.

Horwitz, Elaine. Surveying Students' Beliefs about Language Learning. In Learner Strategies in Language Learning, Eds. A. Wenden and J. Rubin. Englewood, N.J.: Prentice-Hall International, Ltd., 1987.

Jackins, Harvey. The Human Side of Human Beings: The Theory of Reevaluation Counselling. Seattle, Washington: Rational Island Publishers, 1965.

Kazin, Alfred. The Word Was My Agony. In About Language: Contexts for College Writing, Eds. M. Clark, et al. New York: Charles Scribner's Sons, 1975.

Lado, Robert. Linguistics across Cultures. Ann Arbor: The University of Michigan Press, 1957.

Naiman, Neil, Maria Fröhlich, H. H. Stern and A. Todesco. The Good Language Learner. Ontario, Ontario Institute for Studies in Education, 1978.

Omaggio, Alice C. Successful Language Learners: What Do We Know about Them? Washington, D.C.: ERIC/CLL News Bulletin, May 1978.

Postman, Neil. The Demeaning of Meaning: Or What's the Language Pollution Index Today? In The Language Lens, Eds. B. Borah and S. Shively. Englewood Cliffs, N.J.: Prentice-Hall, Inc., 1974.

Rogers, Carl R. Client-Centered Therapy. Boston: Houghton Mifflin Co., 1951.

Rosenthal, Marilyn R. The Magic Boxes: Children and Black English. Arlington, VA.: CAL-ERIC/CLL, 1977. 
Rubin, Joan. What the Good Language Learner Can Teach Us. TESOL Quarterly 9. 1975: 41-51.

Rubin, Joan and Irene Thompson. How to Be a More Successful Language Learner. Boston, Mass.: Heinle and Heinle Publishers, Inc., 1982.

Shannon, Claude E. and Warren Weaver. The Mathematical Theory of Communication. Glencoe, Illinois: Scott, Foresman, 1964.

Stern, H. H. What Can We Learn from the Good Language Learner? Canadian Modern Language Review 31. 1975: 304-318.

Stevick, Earl W. Memory, Meaning and Method: Some Psychological Perspectives on Language Learning. Rowley, Mass.: Newbury House, 1976.

Wenden, Anita L. Conceptual Background and Utility. In Learner Strategies in Language Learning, Eds. A. Wenden and J. Rubin. Englewood, N.J.: PrenticeHall International, Ltd., 1987.

Wenden, Anita L. The Process of Self-Directed Learning: A Case Study of Adult Language Learning. Diss. Teachers College, Columbia University, 1982.

Wesche, M. B. The Good Adult Language Learners: A Study of Learning Strategies and Personality Factors in an Intensive Course. Diss. University of Toronto, 1975.

\section{THE AUTHOR}

Thelma L. Borodkin holds a Ph.D. in linguistics and counselling. Her interest in counselling stems from the distress she perceived in students engaged in the study of a new language or dialect.

An assistant professor of ESL at Lehman College of CUNY, she has trained teachers in the U.S. and abroad. She has written and spoken widely on ESL and SESD issues. Her books on English for students of agriculture are used in the Israeli agricultural high schools.

Her current interest is in research on the application of the cloze to the teaching of metacognition. 